IJMS 18 (Special Issue), 73-90 (2011)

\title{
IMPACT OF BIODIESEL DEMAND ON THE MALAYSIAN PALM OIL INDUSTRY: A SIMULTANEOUS EQUATIONS APPROACH
}

\author{
SHRI DEWI A/P APPLANAIDU \\ UUM College of Business \\ Universiti Utara Malaysia \\ FATIMAH MOHD. ARSHAD \\ ZULKORNAIN YUSOP \\ Faculty of Economics and Management \\ Universiti Putra Malaysia \\ MAD NASIR SHAMSUDIN \\ Faculty of Agriculture \\ Universiti Putra Malaysia \\ MOHAMMAD HAJI ALIAS \\ Faculty of Economics and Muamalat \\ Universiti Sains Islam Malaysia
}

\begin{abstract}
The European Union (EU) Renewable Energy Directive set a target of 20 $\%$ share of energy from the renewable sources and $10 \%$ share of renewable energy specifically in the transport sector. This has resulted in some countries looking for bio-based alternative energies which lead to the increase in demand for bio-based feedstocks such as palm and rapeseed oil (for biodiesel) and sugar cane and corn (for ethanol). One of the new elements in the palm oil market is the growing demand for this commodity as a feedstock to biodiesel production. This will also put Malaysia in a better light on the international front for taking the effort to reduce carbon emissions. In line with this, the palm oil sector in Malaysia will be able to match the New Economic Model's (NEM) major goals of high income, sustainability and inclusiveness. This new development is affecting the dynamics of the market, in particular, the supply and demand sectors of this commodity. This paper seeks to examine the impact of biodiesel demand on the Malaysian palm oil industry. This paper proposes a structural econometric model consisting of nine structural equations and four identities. The model has been estimated by the two stage least squares method using annual data for the period 1976-2010.
\end{abstract}


The specification of the structural model is based on a series of assumptions about general economic conditions, agricultural policies and technological change. The study indicates that counterfactual simulation of a sustained $30 \%$ increase in biodiesel demand predicts a positive increase $(2.48 \%)$ in palm oil exports for non-biodiesel, $13 \%$ increase in the domestic price of palm oil and a marginal increase in production. An increase in export demand would make Malaysia more competitive regionally and globally with benefits accruing to all Malaysians. Apart from this, the biodiesel demand income is also sustainable and will position the nation on the right path towards a high income country by 2020.

Keywords: Biodiesel demand, New Economic Model, simultaneous equations, two stage least squares.

\section{Introduction}

Over a few decades of development, the Malaysian palm oil industry has succeeded in becoming a powerful force in the global oils and fats economy. Investments in oil palm planting have been growing, because of its economic advantage, leading to expansion in output that surpassed the average global oils and fats growth. With practical and tempting choices to importers in terms of price competitiveness and its superior attributes for various edible and non-edible applications, its secured supply availability, Malaysia now tops the list of the palm oil exporters. Indeed, the palm oil sector offers Malaysia a sound model for how other sectors should grow and mature by their achievements in harnessing new technology, delivering investments in Africa, developing a skilled labour force and embracing the global market. The palm oil sector can help point the way towards a highincome status.

The National Economic Action Council (NEAC), in comparing the palm oil sector to the electrical and electronics (E\&E) sector, has estimated that unless the E\&E sector is dramatically upgraded, the palm oil sector could become a larger component than E\&E in GDP contribution, rising in nominal terms to $12.2 \%$ of the GDP by 2020 . In terms of high income, the sector's share of real GDP can grow to $7.6 \%$ by 2020 if the value-added gains from efficiency and innovation can be realised. Palm oil exports could also grow by $7 \%$ per annum to RM84 billion by 2020, and probably more if new oil palm products and services can be successfully marketed. The sector employs 590,000 direct workers versus 316,956 in the E\&E sector. As for sustainability, 
better R\&D will help to improve productivity, better conservation of the environment and lower net carbon impact on operations.

The demand for palm oil is expected to accelerate further with the flourishing biofuel industry both locally and at the global levels. The rapid increase in the price of petroleum above the price of vegetable oils beginning in 2004 has given impetus for the conversion of vegetable oils into biodiesel for transportation fuel. The cheaper palm oil, soybean oil or rapeseed oil could be converted into biodiesel or methyl esters. The biodiesel could then be sold at the price of petroleum diesel thus earning a gross margin of up to US\$200 per tonne or $40 \%$ of the price of vegetable oils (Yusof, 2008). Palm oil is anticipated to become the number one feedstock for biodiesel production due to its price advantage and also its high yields.

The development of the Malaysian biofuel industry boosted the importance of this commodity; it being an economically ideal feedstock for biodiesel production. A number of factors motivate the development of the biodiesel industry in Malaysia. First, the introduction of biodiesel as an alternative fuel will help the government reduce spending on fuel subsidies. Secondly, it provides an alternative energy source for the transportation and industrial sectors thereby reducing fossil fuel consumption that affects the country's oil reserves. Thirdly, producing palm oil-based biodiesel for export will generate export revenues and help in ensuring the increase in the prices of the Malaysian palm oil. Fourth is "the economic argument that biofuel can create employment and income opportunities for local farmers" (Fatimah, 2008). Moreover, Malaysia is one of the signatory countries of the Kyoto Protocol and has ratified to reduce greenhouse gas emissions. The use of palm biodiesel would lower emissions of greenhouse gases by decreasing the use of fossil fuel.

The growing demand for palm oil as a feedstock to biodiesel production will put Malaysia in a better light on the international front for contributing to the effort to reduce carbon dioxide emission and reduce the usage of fossil fuels. In line with this, the palm oil sector in Malaysia will be able to contribute to the achievement of the New Economic Model's (NEM) major goals of high income, sustainability and inclusiveness. This new development-i.e increasing utilisation of palm oil for biodiesel production - is affecting the dynamics of the supply and demand of the palm oil market. This paper seeks to examine the impact of biodiesel demand on the major variables of the Malaysian palm oil industry, in particular, export demand and the price of palm oil. 
Many studies have been conducted to investigate the palm oil market. As monitoring of any commodity market is an evolutionary procedure, especially the Malaysian palm oil market which has witnessed many recent developments, it is realized that a timely study to investigate the changes in the market variables and the impact of these changes on the industry is very important. Thus, this paper reports the findings of an empirical study using a structural simultaneous equations model on the impact of biodiesel demand on the Malaysian palm oil export and price, and provides an updated tool for policy makers.

The remainder of the paper is organized as follows: Section 2 briefly reviews the literature on previous studies on the palm oil industry and the methodologies used for examining the market variables behaviour, section 3 is the model specification, section 4 reports and discusses the results while a summary and some conclusions are presented in section 5 .

\section{Literature Review}

The relatively simple generalized theoretical model has been widely applied to most of the agricultural commodities (such as palm oil, soybean oil, rubber and cocoa). In Malaysia, it also been applied to analyse and model the palm oil, rubber and cocoa market. In terms of palm oil, the structure is refined to ease the penetration in the international market. Previous work of Malaysian palm oil market was done by Yusoff (1988), Au and Boyd (1992), Shamsudin and Arshad (1993) and Talib and Darawi (2002). There is also a study on factors affecting palm oil prices and forecasting palm oil prices using various techniques (Arshad \& Ghaffar, 1987; Shamsudin, Mohamed \& Arshad, 1988 and Shamsudin, Arshad, Mohamed \& Lubis, 1994). Yusoff (1988) incorporated export tax and exchange rate in his work. Later a study by Abdullah, Amiruddin and Ibrahim (1993) simulated the Malaysian palm oil market using all the factors affecting palm oil in Malaysia. Shamsudin et al. (1994) expanded the earlier works on the palm oil model by differentiating the supply response of the estate and smallholder sectors and the diverse nature of the export market. Mohammad, Jani and Abdullah (1999) have done a simulation study of the impact of liberalization of crude palm oil imports from Indonesia. Talib and Darawi (2002). carried out an economic analysis of the Malaysian palm oil market using annual data for the period 1970 and 1999. They identified the important factors that affect the market. The domestic features as well as the imports and exports are included to measure its performance in the international trade. Mohammad and 
Tang (2001) have analysed the supply response of the Malaysian palm oil market using the Engle and Granger (1987) cointegration and error correction approach. A study by Abdullah, Abas and Ayatollah (2007) on the impact of palm oil-based biodiesel demand on palm oil-price is a new attempt to include biodiesel demand in the price equation by using the Time Varying Parameter. The most recent study by Shri Dewi et al. (2011) analysed the link between biodiesel demand and Malaysian palm oil market by using the econometric method using annual data for the period 1976-2008. This study included the role of stationarity and cointegration as a prerequisite test before proceeding to the simultaneous equation estimation procedure.

A simulation study on the impact of the exchange rate variation was done by Mohammad, Shri Dewi and Ali (2006). There is also a study on the impact of the structural change of the Indonesian production on the Malaysian palm oil market (Shri Dewi, Mohammad \& Ali, 2007) between 1976 and 2005. The study of the impact of liberalizing trade on Malaysian palm oil was done by Talib, Jani, Mamat and Zakaria (2007). Later, Shri Dewi and Mohammad (2009) analysed the rising importance of the Indonesian palm oil production with the impact on the Malaysian palm oil market extending the previous study period in Shri Dewi et al. (2007) from 2005 till 2008. There are also studies using the application of a system dynamics approach to the Malaysian palm oil industry but it has been limited with the exception of Kennedy (2006) and Yahaya et al. (2006). Both these studies examine the biodiesel, crude palm oil and petroleum price linkages.

The limitations of previous research are threefold. First, the export equation has been divided into the export of palm oil for biodiesel and the export of palm oil for non-biodiesel which the previous studies have not examined so far. Second, most of the previous Malaysian palm oil studies (Abdullah et al., 1993; Talib \& Darawi, 2002; Mohammad et al., 2006; Shri Dewi et al., 2007 and Talib et al., 2007) have ignored the role of stationarity and cointegration as a prerequisite test before proceeding to the simultaneous equation estimation procedure. Over time, most of the macroeconomic variables show a trending behaviour. This phenomenon is known as non-stationary time series in econometrics. There might be spurious regression due to the presence of non-stationary variables (Granger \& Newbold, 1974). It is inappropriate to make any valid statistical inference with the non-stationary data. Based on these current developments, a few empirical studies applied the simultaneous equation model using 2SLS (Robledo, 2002; Sekhar, 2003a; Sekhar, 
2003b; Song, 2006; Sekhar, 2008 \& Shri Dewi et al., 2011). As such, the Malaysian palm oil market model will be estimated using this procedure. Finally, we are unaware of any studies using more recent data in simultaneous equation models to examine the role of the biodiesel on the Malaysian palm oil market especially the inclusion of the biodiesel demand variable in the model and the impact of this new variable on the Malaysian palm oil export.

\section{Model Specification}

The impact of biodiesel demand on Malaysian palm oil export is measured by a system of equations that consists of the structural econometric model of nine behavioural equations and four identities. A further explanation of the model is given in Mohammad et al. (1999), Shri Dewi et al. (2007) and Shri Dewi et al. (2011). The behavioural equations describe the determination of the Malaysian palm oil supply, domestic consumption, palm oil exports of biodiesel, palm oil exports for non-biodiesel, palm oil import and palm oil domestic prices. From the world perspective, rest of the world excess supply, world excess demand and world palm oil price are included. This model is closed with an identity defining ending period stock level, Malaysian excess supply, world excess supply and world stock (see Table 1).

Table 1

Model Listing

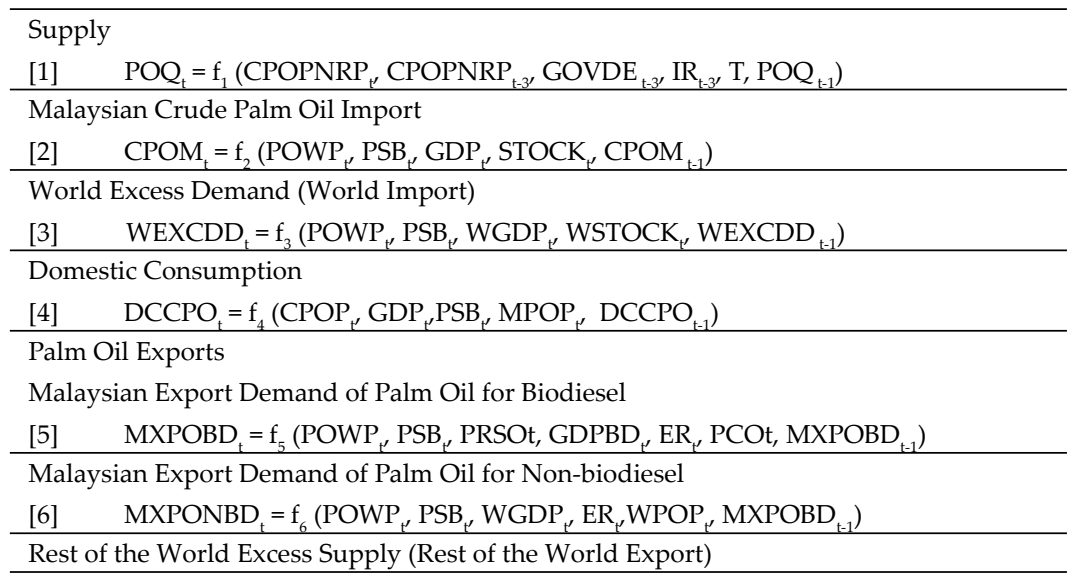

(continued) 


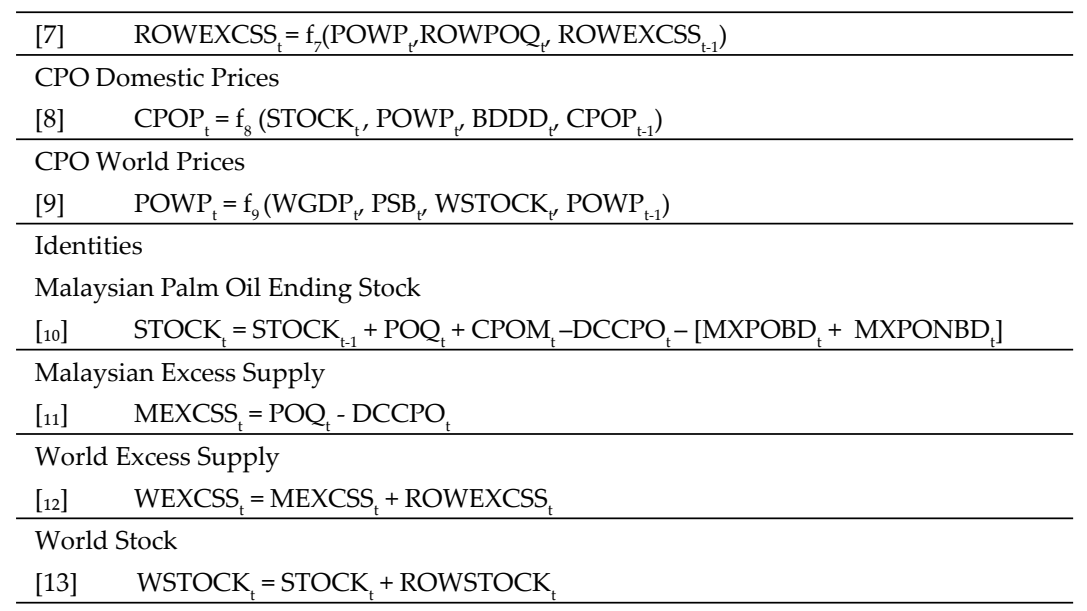

Note. Definition and classification of variables are given in Table 2.

Table 2

Definition and Classification of Variables

Definition of Variables

a. Endogenous Variables

1. $P_{\mathrm{t}}$

2. WEXCDD

3. $\mathrm{DCCPO}_{t}$

4. $\mathrm{MXPOBD}_{\mathrm{t}}$

5. MXPONBD $_{t}$

6. ROWEXCSS

7. $\mathrm{CPOP}_{t}$

8. POWP $_{t}$

9. STOCK $_{t}$

10. MEXCSS $_{t}$

11. WEXCSS

12. WSTOCK $_{t}$

13. WEXCDD
$=$ Palm oil production (tonnes)

$=$ Palm oil import (tonnes)

$=$ World excess demand (tonnes)

$=$ Domestic consumption of palm oil (tonnes)

$=$ Export demand of palm oil for biodiesel (tonnes)

$=$ Export demand of palm oil for nonbiodiesel (tonnes)

$=$ Rest of the world excess supply (tonnes)

$=$ Real domestic price of $\mathrm{CPO}(\mathrm{RM} /$ tonne $)$

$=$ Real world price of $\mathrm{CPO}$ (USD/tonne)

$=$ Malaysian ending stock (tonnes)

$=$ Malaysian excess supply (tonnes)

$=$ World excess supply (tonnes)

$=$ World stock (tonnes) 
IJMS 18 (Special Issue), 73-90 (2011)

\section{Definition of Variables}

b. Exogenous Variables

1. CPOPNRP $_{t}$

2. CPOPNRP $_{t-3}$

3. $\mathrm{GOVDE}_{\mathrm{t}-3}$

4. $\mathrm{IR}_{\mathrm{t}-3}$

5. $\mathrm{T}_{\mathrm{t}}$

6. $\mathrm{PSB}_{\mathrm{t}}$

7. $\mathrm{GDP}_{\mathrm{t}}$

8. WGDP $_{t}$

9. WSTOCK

10. $\mathrm{MPOP}_{\mathrm{t}}$

11. $\mathrm{PRSO}_{t}$

12. $\mathrm{GDPBD}_{\mathrm{t}}$

13. $\mathrm{ER}_{\mathrm{t}}$

14. $\mathrm{PCO}_{\mathrm{t}}$

15. $\mathrm{WPOP}_{\mathrm{t}}$

16. ROWPOQ

17. BDDDt

18. ROWSTOCK

c. Predetermined Variables

1. $P O Q t_{-1}$

2. $\mathrm{CPOM}_{\mathrm{t}-1}$

3. WEXCDD

4. $\mathrm{DCCPO}_{\mathrm{t}-1}$

5. $\mathrm{MXPOBD}_{\mathrm{t}-1}$
$=$ Relative price of $\mathrm{CPO}$ and natural rubber

$=$ Relative price of $\mathrm{CPO}$ and natural rubber lag three years

$=$ Government agricultural and rural development expenditure lag 3 years (RM million)

$=\quad$ Interest rate lag three years $(\%)$

$=$ Time trend

$=$ World price of soybean oil (USD/tonnes)

$=$ Malaysia GDP (RM million)

$=$ World income (USD million)

$=$ World stock of palm oil (tonnes)

$=$ Malaysian population (million people)

$=$ Real price of rapeseed oil (USD/tonnel)

$=$ Biodiesel importing countries GDP (USD billion)

$=$ Exchange rate $(\mathrm{RM} / \mathrm{USD})$

$=$ Price of crude oil (USD/barrel)

$=$ World population (million people)

$=$ Rest of the world production (tonnes)

$=$ Biodiesel demand (tonnes)

$=$ Rest of the world stock of palm oil (tonnes)

$=$ Malaysian production of $\mathrm{CPO}$ lag one year (tonnes)

$=\quad$ Palm oil import lag one year (tonnes)

$=$ World excess demand lag one year (tonnes)

$=$ Domestic consumption lag 1 year (tonnes)

$=$ Export demand of palm oil for biodiesel lag 1 year (tonnes) 
IJMS 18 (Special Issue), 73-90 (2011)

\begin{tabular}{|c|c|c|}
\hline \multicolumn{3}{|c|}{ Definition of Variables } \\
\hline 6. $\mathrm{MXPONBD}_{\mathrm{t}-1}$ & & $\begin{array}{l}\text { Export demand of palm oil for non- } \\
\text { biodiesel lag } 1 \text { year (tonnes) }\end{array}$ \\
\hline 7. ROWEXCSS $_{\mathrm{t}-1}$ & $=$ & $\begin{array}{l}\text { Rest of the world excess supply lag } 1 \\
\text { year (tonnes) }\end{array}$ \\
\hline 8. $\mathrm{CPOP}_{\mathrm{t}-1}$ & $=$ & $\begin{array}{l}\text { Domestic price of CPO lag one year (RM/ } \\
\text { tonne) }\end{array}$ \\
\hline 9. $\mathrm{POWP}_{\mathrm{t}-1}$ & & $\begin{array}{l}\text { World price of palm oil lag } 1 \text { year (USD/ } \\
\text { tonne) }\end{array}$ \\
\hline 10. STOCK $_{\mathrm{t}-1}$ & $=$ & Stock one period lag (tonnes) \\
\hline
\end{tabular}

It is useful to check the order and rank conditions of a model. Once the order and rank condition is fulfilled, then the stationarity and cointegrating test will be carried out. All the variables in each of the equations are tested for stationarity and order of integration using the Augmented Dickey-Fuller (1979), Phillips and Perron (1988) and Kwiatkowski, Phillips, Schmidt and Shin (1992) test. The cointegration and non-stationarity do not call for a new estimation method or statistical inference. The conventional 2SLS methods for estimating and testing simultaneous equation models are still valid for structural models (Hsiao, 1997). Since the long-run equilibrium is observed in the real world, there must be a cointegration when the time series are integrated together with the satisfaction in rank and order condition. As such, the Malaysian palm oil market model will be estimated using the procedures mentioned.

The direct effect of an increase in biodiesel demand on the Malaysian industry is through the crude palm oil (CPO) prices. We postulate a positive relationship between biodiesel demand (BDDD) and CPO prices. With an increase in BDDD, indirect effects on the Malaysian palm oil industry are through the price transmission channel of $\mathrm{CPO}$ prices. The increase in $\mathrm{CPO}$ prices in turn increases $\mathrm{CPO}$ production but decreases the domestic consumption. These changes would result in an increase in the Malaysian palm oil stock. An increase in the stock would also lead to an increase in the world stock. An increase in the world stock decreases the world $\mathrm{CPO}$ prices. The price for $\mathrm{CPO}$ is determined in the world market and the inclusion of BDDD is to test the significance of increasing Malaysian biodiesel demand in price determination. Dynamic responses are modelled using partial adjustment mechanisms.

This study utilised secondary data obtained from the publications of the Department of Statistics of Malaysia, the Malaysian Palm Oil 
IJMS 18 (Special Issue), 73-90 (2011)

Board (MPOB), and various editions of the Oil World and International Financial Statistics (IFS) of the International Monetary Fund (IMF). Annual data from 1976-2010 were used in this study.

\section{Analysis of Results}

All the behavioural equations satisfied the order and condition for identification. The test of stationarity ADF, PP and KPSS showed that the residuals of the equations are stationary. The simultaneous equation framework was carried out to estimate the coefficients. The non-linear 2SLS estimates obtained from this study were quite satisfactory in terms of high $\mathrm{R}^{2}$, significance of the coefficients of the variables and the correct signs. A modified 2SLS-Cochrane Orcutt procedure (see Pindyck Rubinfeld, 1991; and Ramanathan, 1992) was subsequently used to estimate all equations because autocorrelation was found to be present. To detect heteroscedasticity, autocorrelation, and non-normality, other possible forms of model mis-specification were conducted in the various tests. Disturbance terms in all equations were homoscedastic. Finally, the relevant Durbin Watson statistics (DW) and h-statistics showed that there was no autocorrelation problem.

The results suggest that the production of crude palm oil in Malaysia was determined by the ratio of its price with rubber, interest rate, government development expenditure on agriculture and time trend. All of the estimated coefficients in the supply equation of palm oil have the expected signs. The relative price of palm oil and rubber lagged three years was significant at the ten per cent level even though the lag one year relative price was found not to be an important determinant of palm oil production. An increase of one per cent in the relative price of lag three years leads to a 0.0001 per cent increase in palm oil production. This finding is consistent with the findings of Alias et al. (2001) and Alias and Tang (2005) on supply response of Malaysian palm oil producers and a study by Remali et al. (1998) on Malaysian cocoa supply response. This reflects the importance of this variable at the time the investment was made.

The interest rate variable was included to account for the cost of borrowing and it was found to be negative according to the theory.

The estimates obtained for the import demand were consistent with a priori expectations. As expected, Malaysian imports of $\mathrm{CPO}$ were negatively related to the price of world palm oil but positively related to the price of soybean. The coefficient of the price of soybean 
was found to be negative even though statistically insignificant. The coefficient of the Malaysian GDP was found to be positive. As expected, the coefficient of beginning stocks has a negative sign, even though it is statistically insignificant.

The empirical estimates of world excess demand (world import) suggested that the primary factors affecting changes in world imports were world price, world price of soybean, world income, world stock and lagged one year of world import. The own price elasticity was estimated at 0.2962 . This value was similar to the elasticity estimated by Shamsudin et al. (1997) at 0.278 . The world income was significant at one per cent level and had the expected sign.

The domestic demand equation (domestic consumption) was based on the Marshallian demand function. The domestic demand was empirically affected by the own price, Malaysian GDP, price of soybean and lagged domestic demand. All of the variables were significant at least at the ten per cent level, except the price of the substitute (soybean). The adjustment coefficient being 0.39 indicated a moderate adjustment to the equilibrium level. An increase in the own price by one per cent would decrease domestic utilization by $0.08 \%$. These results showed an inelastic value for own price which was supported by Talib and Darawi (2002) with 0.388 compared to Shamsudin et al. (1997) where the elasticity was estimated at 0.242. In the short-run, given a 1 per cent increase in Malaysian GDP, the domestic consumption would only increase by $0.71 \%$. The coefficient of the current price of soybean oil was positive following the expected sign. However, this coefficient was not statistically significant, implying that the consumption level of palm oil depended on the soybean price and one year lagged consumption. The coefficient of lagged domestic demand was also significant indicating that the lagged adjustment model was appropriate. The adjustment coefficient was calculated at 0.39 , suggesting that adjustment to the desired level of domestic consumption were rapid at about 39\% per year. The results were consistent with earlier studies such as that by Yusoff (1988), Shamsudin et al. (1988), Mohammad et al. (1999), Mohammad et al. (2006) and Shri Dewi et al. (2007).

An examination of these results indicated that the biodiesel export demand function has a reasonably good fit and all the variables have expected signs and significant coefficients. The coefficients for own and substitute prices, exchange rate, biodiesel importing countries, GDP and price of crude oil were significant at least at the 5\% level. The own price elasticity was -0.3752 . The results confirmed the findings 
by Yusoff and Salleh (1987), Shamsudin et al. (1993) and Shamsudin et al. (1988) that the export demand for agricultural demand was inelastic. Findings by Park and Fortenbery (2007) further confirmed that the own price was inelastic for ethanol consumption. An increase in the price of rape seed oil by one per cent would increase the palm oil used for biodiesel export by $2.80 \%$. This coefficient suggested that it is a substitute for the export of biodiesel. In this equation the GDP of the biodiesel importing countries were used as a proxy for world income or industrial production index. This is adopted from Taylor et al. (2006) and Park and Fortenberry (2007). The GDP of biodiesel importing countries showed a positive sign and was significant at the $1 \%$ level suggesting export demand would increase following the increase in the GDP of the biodiesel importing countries. The price of crude oil shows a positive sign with an inelastic value of 0.60 and was significant at the $5 \%$ level suggesting that export of palm oil for biodiesel would follow the increase in energy prices especially crude oil.

The export demand function of palm oil for non-biodiesel purposes was determined by palm oil world price, exchange rate, price of soybean (PSB), world income and lagged dependent variables. All the coefficients were significant at least at the $10 \%$ level. The ownprice elasticities of palm oil in the short-run were in the inelastic range $(-0.6909)$, where the findings were consistent with Talib and Darawi (2002) with -0.388 which suggests that they were more inelastic than the results found by Shamsuddin and Arshad (1993), i.e. own-price elasticities in the short-run was -0.45 . An increase of one per cent in the price of soybean, would lead to $0.6706 \%$ increase in the palm oil export for non-biodiesel purpose. This finding was consistent with the findings of Talib and Darawi (2002) with the elasticities of 0.103.

The rest of the world export was mainly determined by the production in the rest of the world. The production variable was significant at the five per cent level. Event hough the world price variable had the expected sign, it was not statistically significant. The coefficient of the rest of the world export lagged one year also had the expected sign and was statistically significant. The speed of adjustment shows that the adjustment to the desired level of the rest of the world exports was very high; 0.9008 .

All the estimated coefficients in the domestic price equation have the expected signs. The price flexibilities with respect to stock and world price were -1.2938 and 1.0981 , respectively. The biodiesel demand variable was included as a proxy to model the effect of rising 
importance of biodiesel demand. The coefficient of this variable was 0.0695 which was statistically significant at the ten per cent level and followed the correct sign. The coefficients on lagged prices indicated that the adjustment price to the equilibrium was relatively fast (0.8794). The results were consistent with the findings of Hwa (1979) and Shamsudin et al. (1993) that stock disequilibrium determined the changes in primary commodity prices and also the speed of adjustment was generally faster for agricultural commodities. The speed of adjustment in Abdullah and Lazim (2006) was also found to be consistent with this study; 0.6618 .

In the case of the equation for the palm oil world price, it was found that all the variables could explain the variation; price of soybean, world GDP, world stock and the lagged dependent variable. Price of soybean was found to be significant at the 1 per cent level where this confirmed the belief that soybean oil was palm oil's main substitute and both oils competed in the international fats and oils market. The result was consistent with Yusoff (1988) and Talib et al. (2007). Thus, a one per cent increase in the price of soybean would result in a 1.0966 per cent increase in the palm oil world price. The other variable, the world income (WGDP) is also significant at the one per cent level.

Overall, the estimation results of the Malaysian palm oil market model were statistically acceptable. Some of the coefficients were found not to be significant but we retained them on a priori ground, i.e. we believe that the variables were relevant, but because of possible data and econometric problems, accurate estimates were not possible.

\section{Simulation on a Sustained $\mathbf{3 0} \%$ Increase in Palm-based Biodiesel Demand}

In the An analysis of the results of the estimated structural model of the Malaysian palm oil industry using the 2SLS method based on the annual data for the period 1976 to 2010 . The above few paragraphs explain structurally the model of the Malaysian palm oil market using the 2SLS method during the period 1976 and 2010. Some of the equations in the model are highly significant and the others are not. The significance of each equation in the model is less important than the set as a whole. Therefore it is important to check on the overall ability of the model to simulate well.

A counterfactual simulation of our model has been carried out to analyse the impact of sustained increase in the biodiesel demand on the Malaysian palm oil exports. To gauge the impact of the 
increasing trend in Malaysian biodiesel demand, a counterfactual $30 \%$ increase in the Malaysian biodiesel demand from year 2006 to 2010 was imposed on the model. The counterfactual simulation of the model was carried out. The simulated values of all the endogeneous variables were compared to the baseline solutions. The counterfactual results are given in Table 3.

Table 3

Impact of Increase in Biodiesel Demand (Counterfactual Analysis)

\begin{tabular}{lc}
\hline Variables & $\begin{array}{c}\text { The effects of } 30 \% \text { increase in } \\
\text { biodiesel demand (\%) }\end{array}$ \\
\hline Domestic Price & 13.02 \\
Palm Oil Production & 0.57 \\
Domestic Consumption & -0.0001 \\
Malaysian Palm Stock & 0.12 \\
World Stock & 0.01 \\
Palm Oil World Price & -1.55 \\
Export of Palm Oil for Biodiesel & 0.14 \\
Export of Palm Oil for Non-biodiesel & 2.48 \\
\hline
\end{tabular}

The model is able to simulate the impact of $30 \%$ increase in palmbased biodiesel demand. The directions of the responses are in general, consistent with the predictions of the theory. The increase of $30 \%$ in palm-based biodiesel demand leads to an increase in domestic price (CPOP). The CPOP increase is expected to be about $13.02 \%$. Despite the significant increase in the CPO prices, the production response was low. The relatively low response was because of low price elasticity of supply (see also Mohamed Berawi, 2004). As shown in Table 2 , the production increased only by $0.57 \%$. As expected, this increase led to a decrease in the domestic consumption by 0.0001 per cent.

The Malaysian palm oil stock (stock availability) would increase by $0.12 \%$. This was due to the net changes from the increase in CPO production and a decrease in domestic demand. An increase in the world stock (due to an increase in the Malaysian stock) would depress the palm oil world price by $1.55 \%$. A decrease in the palm oil world price would increase the export of palm oil for biodiesel by $0.14 \%$. The immediate sudden loss due to the increase in biodiesel demand would be offset through an increase in import especially 
from Indonesia and local production. A decrease in the palm oil world price also increased the Malaysian export of palm oil for nonbiodiesel purposes by 2.48 per cent.

\section{Summary and Conclusions}

The econometric simulations suggest that biodiesel demand does bring positive economic impacts on selected sub-sectors of the palm oil industry especially the producers because of the significant increase in the domestic price of palm oil. In particular a counterfactual simulation of a sustained 30\% increase in biodiesel demand predicts a positive increase $(2.48 \%)$ in palm oil exports for non-biodiesel, a $13 \%$ increase in the domestic price of palm oil and a marginal increase in production.

The study suggests that the production of palm oil as a feedstock to biodiesel in Malaysia increases in response to the biofuel demand. However future expansion may be hindered because of land constraint and increasing cost of inputs such as labour, fertiliser and services. Malaysia has opted to invest offshore, in a bid to reduce the cost of production in the ASEAN countries such as Indonesia, Papua New Guinea and lately in selected African countries.

An increase in export demand would make Malaysia more competitive regionally and globally with benefits accruing to all Malaysians. Apart from this, the biodiesel demand income is also sustainable and will position the nation on the right path towards a high income country by 2020 . One clear impact of the increase in biodiesel demand is the increase in price of palm oil as has been shown in 2008 when crude oil price was at its peak. The industry's worth was estimated at RM60 billion in 2009 which was about 9\% of the country's GDP, a record unmatched before. The high price was a boon to the industry participants such as producers, millers, biodiesel companies and the government. In particular, farmers smallholder palm oil producers - will benefit from the high prices of vegetable oils. Since the smallholder sector makes up $40 \%$ of the oil palm planted areas in Malaysia, it is among the crucial components in the country's palm oil industry. The efforts to improve productivity and income are in line with the goal of the Economic Transformation Programme to transform Malaysia into a high-income nation by 2020. The future trend for palm oil price is positive given the new potential demand from biodiesel which will lead to a major supply and which imbalance in the fats and oils market. This is because the fats and oils 
IJMS 18 (Special Issue), 73-90 (2011)

markets cannot increase supply rapidly to match the rapid increase in biodiesel demand. The driver of the food fats and oils prices will be the petroleum prices.

\section{References}

Abdullah, R., Abas, R., \& Ayatollah, K. (2007). Impact of palm oilbased biodiesel demand on palm oil price. Oil Palm Industry Economic Journal, 7(2), 19-27.

Abdullah, R., Amirudin, M. N., \& Ibrahim, A. (1993). An econometric model simulating the Malaysian palm oil market. PORIM Buletin, 26, 27-38.

Abdullah, R., \& Lazim, M. A. (2006). Production and price forecast for Malaysian palm oil. Oil Palm Industry Economic Journal, 6(1), 39-45.

Arshad, F. M., \& Ghaffar, R. A. (1987). Stochastic modelling of crude palm oil production revisited. Occasional Paper. 11: Centre for Agricultural Policy Studies. University of Agriculture Malaysia.

Au, K., \& Boyd, M. S. (1992). An analysis of supply response, exports demand and stocks for Malaysian palm oil. Malaysian Journal of Agricultural Economics, 9(1), 47-58.

Bank Negara Malaysia. (2009). Bank Negara Malaysia Annual Report 2008, p.25.

Engle, R. F., \& Granger, C. W. J. (1987). Cointegration and error correction: Representation, estimation and testing. Econometrica, 55(2), 251-276.

Engle, R. F., \& Granger, C. W. J. (1987). Cointegration and dynamic simultaneous equations models. Econometrica, 65(3), 647-670.

Fatimah Mohamed Arshad. (2008). Palm oil based diesel: An inconvenient opportune? Impak - Quarterly DOE Update on Environment, Development \& Sustainability, Issue 4.

Granger, C. W. J., \& Newbold, P. (1974). Spurious regressions in econometrics. Journal of Econometrics, 2,111-120.

Hsiao, C. (1997). Statistical properties of the two stage least squares estimator under cointegration. Review of Economic Studies, 64, 385-398.

Hwa, E. C. (1979). Price determination in several international primary commodity markets: A structural analysis. IMF Staff Papers, 26,157-188.

Kennedy. (2006). An evaluation of biodiesel, crude palm oil and petroleum price linkages. Report prepared for Golden Hope Plantations Bhd. STE Consulting. 
Malaysian Palm Oil Board (MPOB). (2010). Economics and Industry development division export statistics. Retrieved from http://econ. mpob.gov.my/economy/EID_web.htm

Mohamed Berawi, Fuad. (2004). Respons penawaran pengeluar minyak sawit Malaysia: Model harta jangkaan. International Journal of Management Studies, 11(1\&2), 145-164.

Mohammad, H. A., Jani, M. F. M., \& Abdullah, R. (1999). Interactions between Malaysia and Indonesian palm oil industries: Simulating the impact of liberalization of imports of CPO from Indonesia. Journal of Oil Palm Research, 11(2), 46-56.

Mohammad, H. A., Shri Dewi, S., \& Ali, A. M. (2006). Variasi kadar pertukaran matawang dan harga minyak sawit: Analisis berdasarkan satu model struktur. Jurnal Ekonomi Malaysia, 40, 3-25.

Mohammad, H. A., \& Tang, T. C. (2005). Supply response of Malaysian palm oil producers: Impact of interest rate variations. Oil Palm Industry Economic Journal, 5(2), 11-22.

Park, H., \& Fortenbery, T. R. (2007). The effect of ethanol production on the U.S national corn price. Proceedings of the NCCC-134 Conference on Applied Commodity Price Analysis, Forecasting and Market Risk Management. Chicago, IL. Retrieved from http:// www.farmdoc.uiuc.edu/

Pyndick, R. S., \& Rubinfeld, D. L. (1998). Economic models and economic forecasts (4th ed.). Boston: Irwin/Mc Graw Hill.

Ramanathan, R. (1992). Introductory econometrics with applications. Dryden Press.

Robledo, C. W. (2002). Dynamic econometric modeling of the U.S wheat grain market (Unpublished doctoral dissertation). Louisiana State University.

Sekhar, C. S. C. (2003a). Price formation in world wheat markets: Implications for policy. Journal of Policy Modeling, 25(1), 85-106.

Sekhar, C. S. C. (2003b). Determinants of price in world wheat markets-hidden lessons for Indian policy makers? Indian Economic Review, 38, 167-187.

Sekhar, C. S. C. (2008). Price formation in world soybean oil market: An econometric analysis. Indian Economic Review, 43(2), 183204.

Shamsudin, M. N., Arshad, F. M., \& Fuziah. (1997). The effect of export duty liberalization on the palm oil industry. Malaysian Oil Science and Technology, 6(2), 79-82.

Shamsudin, M. N., \& Arshad, F.M. (1993). Malaysian palm oil market model. In F. M. Arshad, M. N. Shamsudin, \& M.S. Othman (Eds.), Malaysian agricultural commodity forecasting and policy modelling. 
IJMS 18 (Special Issue), 73-90 (2011)

Center for Agricultural Policy Studies.

Shamsudin, M. N., Mohamed, Z. A., \& Arshad, F. M. (1988). Selected factors affecting palm oil prices. Malaysian Journal of Agricultural Economics, 5(1), 20-29.

Shamsudin, M. N., Arshad, F. M., Mohamed, Z. A., \& Lubis, A. R. (1994). A market model for Malaysian palm oil industry. The Malaysian Journal of Agricultural Economics, 11(1), 81-102.

Shri Dewi, A., \& Mohammad, H. A. (2009). Rising importance of Indonesian palm oil production: Impact on the Malaysian market. Muamalat Issue, 6(1), 2-5.

Shri Dewi, S., Mohammad, H. A., \& Ali, A. M. (2007). Rising assendency in Indonesian production: Impact on the Malaysian palm oil market. Jurnal Kinabalu, 13, 125-139.

Shri Dewi, A., Arshad, F. M., Shamsudin, M. N., \& Awad, A. A. (2011). An econometric analysis of the link between biodiesel demand and Malaysian palm oil market. International Journal of Business and Management , 6(2) 35-45.

Song, N. (2006). Structural forecasting softwood lumber models with time series approach (Unpublished doctoral dissertation). Louisiana State University.

Talib, B. A., \& Darawi, Z. (2002). An economic analysis of the Malaysian palm oil market. Oil Palm Industry Economic Journal, 2(1), 19-27.

Taylor, R. D., Mattson, J. W., and Koo, W. K. (2006). Ethanol's impact on the U.S corn industry. Agribusiness \& Applied Economics Report No. 580. Centre for Agricultural Policy and Trade Studies, Department of Agribusiness and Applied Economics North Dakota State University Fargo, North Dakota.

Yahaya, J., Ahmad, S., \& Kennedy, S. W. (2006). Impacts of biodiesel develoment on the palm oil industry. Malaysian Journal of Economic Studies, XXXXIII (1 \& 2), 1-15.

Yusof, B. (2008). Outlook: Biodiesel impact on the palm oil industry. Global Oils and Fats Business Magazine. Vol. 5 Issue 3 (July-Sept).

Yusoff, M. (1988). Production and trade model for the Malaysian palm-oil industry. ASEAN Economic Bulletin, 169-177. 